Article

\title{
Poly-( $\gamma$-glutamic acid) Production and Optimization from Agro-Industrial Bioresources as Renewable Substrates by Bacillus sp. FBL-2 through Response Surface Methodology
}

\author{
Da-Young Song ${ }^{1}$, Lebaka Veeranjaneya Reddy ${ }^{1,2, * \mathbb{D}}$, Dimitris Charalampopoulos ${ }^{3}$ and \\ Young-Jung Wee ${ }^{1, *(D)}$ \\ 1 Department of Food Science and Technology, Yeungnam University, Gyeongsan Gyeongbuk 38541, Korea; \\ ssongdayoung@daum.net \\ 2 Department of Microbiology, Yogi Vemana University, Kadapa (A.P.) 516003, India \\ 3 Department of Food and Nutritional Sciences, University of Reading, Whiteknights, P.O. Box 226, \\ Reading RG6 6AP, UK; d.charalampopoulos@reading.ac.uk \\ * $\quad$ Correspondence: lvereddy@gmail.com (L.V.R.); yjwee@ynu.ac.kr (Y.-J.W.); Tel.: +82-53-810-2951 (Y.-J.W.)
}

Received: 30 October 2019; Accepted: 19 November 2019; Published: 20 November 2019

\begin{abstract}
We optimized culture conditions using Bacillus sp. FBL-2 as a poly-( $\gamma$-glutamic acid) (PGA) producing strain isolated from cheonggukjang. All experiments were performed under aerobic conditions using a laboratory scale $2.5 \mathrm{~L}$ fermentor. We investigated the effects of fermentation parameters (temperature, $\mathrm{pH}$, agitation, and aeration) and medium components (glutamic acid, citric acid, and yeast extract) on poly-( $\gamma$-glutamic acid) production, viscosity, and dry cell mass. A non-optimized fermentation method ( $1.5 \mathrm{vvm}, 350 \mathrm{rpm}$, and $\left.37^{\circ} \mathrm{C}\right)$ yielded PGA, viscosity, and dry cell mass at levels of $100.7 \mathrm{~g} / \mathrm{L}, 483.2 \mathrm{cP}$, and $3.4 \mathrm{~g} / \mathrm{L}$, respectively. L-glutamic acid, citric acid, and yeast extract supplementation enhanced poly- $(\gamma$-glutamic acid) production to $175.9 \mathrm{~g} / \mathrm{L}$. Additionally, the production of poly-( $\gamma$-glutamic acid $)$ from rice bran and wheat bran was assessed using response surface methodology (central composite rotatable design). Agricultural byproducts (rice bran and wheat bran) and $\mathrm{H}_{2} \mathrm{SO}_{4}$ were selected as factors, and experiments were performed by combining various component concentrations to determine optimal component concentrations. Our experimentally-derived optimal parameters included $38.6 \mathrm{~g} / \mathrm{L}$ of rice bran, $0.42 \%$ of $\mathrm{H}_{2} \mathrm{SO}_{4}$, $28.0 \mathrm{~g} / \mathrm{L}$ of wheat bran, and $0.32 \%$ of $\mathrm{H}_{2} \mathrm{SO}_{4}$. Under optimum conditions, rice bran medium facilitated poly-( $\gamma$-glutamic acid) production of up to $22.64 \mathrm{~g} / \mathrm{L}$, and the use of wheat bran medium yielded up to $14.6 \mathrm{~g} / \mathrm{L}$. Based on a validity test using the optimized culture conditions, poly- $(\gamma$-glutamic acid) was produced at $47.6 \mathrm{~g} / \mathrm{L}$ and $36.4 \mathrm{~g} / \mathrm{L}$ from these respective mediums, and both results were higher than statistically predicted. This study suggests that rice bran can be used as a potential alternative substrate for poly- $(\gamma$-glutamic acid $)$ production.
\end{abstract}

Keywords: Bacillus sp. FBL-2; optimization; rice bran; poly-( $\gamma$-glutamic acid); wheat bran

\section{Introduction}

Poly-( $\gamma$-glutamic acid) (PGA) is a natural polyaminoic acid and biocompatible compound that is naturally synthesized by members of the genus Bacillus during food fermentation. This compound was first discovered by Ivanovics during a study of the film produced by Bacillus anthracis. Later, Bovarnick observed the presence of this compound in Bacillus subtilis growth medium as a freely secreted polymer [1]. Poly- $\gamma$-glutamate is produced as a non-cellular product that is completely biodegradable and soluble in water. Additionally, it is a non-toxic, edible, and environmentally friendly 
substance that can be separated from food [2]. The molecular structure of poly- $(\gamma$-glutamic acid $)$ consists of the repetitive units of D- or L-glutamic acid connected by amide bonds between the $\alpha$-amino and the carboxyl radicals of the monomer of glutamic acid (Figure 1), and this compound exists as an abnormal anionic homopolypeptide [2]. Poly-( $\gamma$-glutamic acid), produced by microorganisms, does not have a fixed molecular weight; however, it typically exists as a macromolecule with a size range of 10 to $1000 \mathrm{kDa}$ [3]. Poly-( $\gamma$-glutamic acid) is a polymer that can be used in a wide range of areas, including food, medical, water treatment, cosmetic, and agricultural industries. In the food industry, it can be used as a food supplement, texture enhancer, cryoprotectant, sedimenter, bitter taste reducing agent, hydrogel, bioflocculant, and genealogical feed additive. It also has numerous applications within the health care industry based on its chemical characteristics [4].
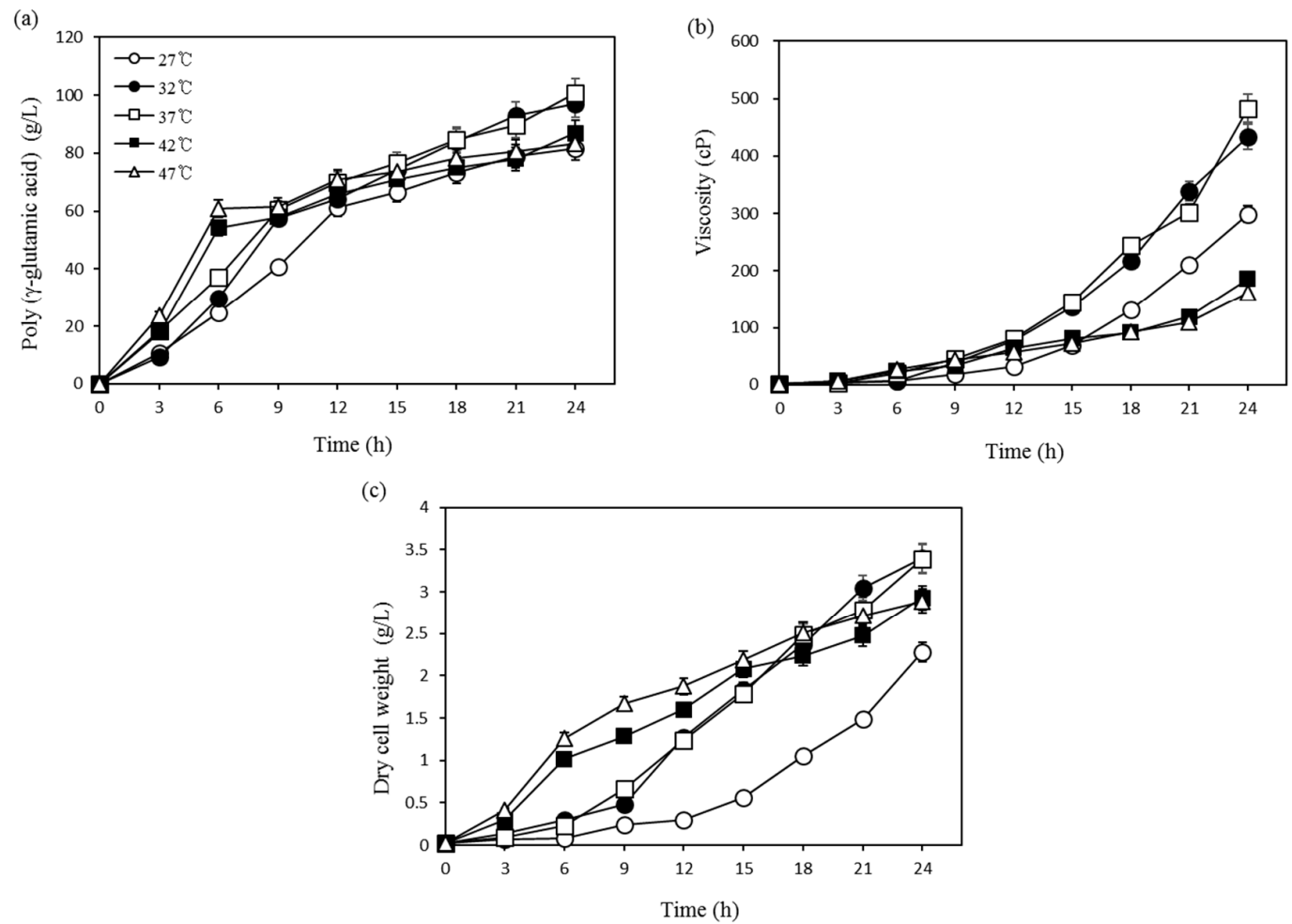

Figure 1. Effects of temperature on (a) poly-( $\gamma$-glutamic acid) production, (b) viscosity, and (c) dry cell weight $(\mathrm{DCW})$.

The bacteria that produce poly-( $\gamma$-glutamic acid) belong to the genus Bacillus, and these bacteria include Bacillus anthracis, Bacillus subtilis, Bacillus licheniformis, Bacillus amyloliquefaciens, and Bacillus methylotrophicus. Each of these microorganisms require different nutritional inputs for the production of poly-( $\gamma$-glutamic acid $)$. Based on this, microbes are classified into two groupsglutamate-dependent and glutamate-independent bacteria [2]. The glutamate-dependent bacteria are B. subtilis (cheonggukjang), B. licheniformis 9945a, B. subtilis CGMCC 0833, B. licheniformis NK-03, and B. subtilis ATCC 15245 (natto). In these bacteria, the yield of poly-( $\gamma$-glutamic acid) increases as the concentration of L-glutamic acid is increased within the growth medium [5]. Independent bacteria are more desirable for industrial production than are dependent bacteria due to their low cost and simple fermentation processes. However, the usefulness of these bacteria is limited in scope compared to that of the dependent bacteria [6].

The polymeric materials produced by microorganisms can be used as novel materials in many industries, and therefore, production must occur in large quantities to satisfy industrial demand [7]. One potential problem is that poly ( $\gamma$-glutamic acid), as a high-molecular material, requires expensive substrates and is restricted in use due to high production costs. To solve this problem, a method is required to produce poly-( $\gamma$-glutamic acid) in a more economical manner by replacing expensive 
substrate with a low-cost substrate. Agricultural byproducts that are disposed as waste and are abundantly available possess sufficient potential as alternative materials for producing poly-( $\gamma$-glutamic acid). In recent years, the suitability of agricultural byproducts such as rice straw [8], molasses [9], and dairy compost [10] has been evaluated. Very recently, Anju et al. [11] investigated the comparative production of poly-( $\gamma$-glutamic acid) from rice straw, sugar cane waste, sugarcane bagasse, cotton stalks, and sorghum stover.

Rice bran and wheat bran are highly utilized materials due to their distribution of nutrients. Rice bran produced during polishing contains $34-62 \%$ carbohydrates, $15-20 \%$ fat, $11-15 \%$ protein, $7-10 \%$ ash, and $7-11 \%$ crude fiber, and although it is a byproduct, it accounts for $95 \%$ of the nutritional value of rice $[12,13]$. Approximately $20-30 \%$ of the total output of rice is used for maintenance extraction, and the remainder is used for feed or compost. Additionally, wheat bran produced during the milling process of wheat contains $15 \%$ protein, $12 \%$ starch, $6 \%$ ash, and $6 \%$ fat, and the majority of the byproducts are used as dietary fiber additives in feed or drinks [14]. The major hurdle in the utilization of these materials as fermentation feedstock is that they cannot be used in their current states by many microorganisms, and instead they require hydrolysis to convert them into simple fermentable sugars. Rice and wheat are among the top three crops worldwide, and their utilization is very low despite the high production of agricultural byproducts [15]. The goal of this study was to determine a means of using these discarded agricultural byproducts for the production of poly-( $\gamma$-glutamic acid). To accomplish this, we proposed three objectives - the optimization of fermentation conditions (temperature, $\mathrm{pH}$, agitation, and aeration) using a one-factor-at-a-time method; the improved production of poly ( $\gamma$-glutamic acid) through repeated batch fermentation by incorporating these optimized fermentation conditions; and the optimization of wheat and rice bran hydrolysis through response surface methodology (RSM) to facilitate the economic production of poly-( $\gamma$-glutamic acid).

\section{Materials and Methods}

\subsection{Bacterial Culture and Inoculum Preparation}

In this study, Bacillus sp. FBL-2 KCTC 12962BP was isolated from cheonggukjang, a fermented soybean paste, and was subsequently used for the production of poly-( $\gamma$-glutamic acid). Inoculum was prepared from the stock culture by inoculating to the culture medium composed of glucose $(10.0 \mathrm{~g} / \mathrm{L})$, yeast extract $(3.0 \mathrm{~g} / \mathrm{L})$, L-glutamic acid $(20.0 \mathrm{~g} / \mathrm{L}), \mathrm{KH} 2 \mathrm{PO} 4(1.0 \mathrm{~g} / \mathrm{L})$, and $\mathrm{MgSO}_{4} \cdot 7 \mathrm{H}_{2} \mathrm{O}(1.0 \mathrm{~g} / \mathrm{L}, \mathrm{pH} 7.0)$. The inoculum was then incubated at $37^{\circ} \mathrm{C}$ on a shaking incubator (Vision Scientific Co., Daejeon, Korea) at $200 \mathrm{rpm}$ for $24 \mathrm{~h}$. To preserve the culture, 50\% (v/v) glycerol was added to the culture as a cryoprotectant, and the cultures were stored at $-70{ }^{\circ} \mathrm{C}$ in a deep freezer until further use.

\subsection{Poly-( $\gamma$-glutamic acid) Production}

The bacterial culture described above was used as inoculum (3\%) to initiate fermentation. The production medium contained sucrose (5\%), L-glutamic acid $(10.5 \%)$, yeast extract $(1.32 \%)$, citric acid $(1 \%), \mathrm{KH}_{2} \mathrm{PO}_{4}(0.1 \%)$, and $\mathrm{MgSO}_{4} \cdot 7 \mathrm{H}_{2} \mathrm{O}(0.1 \%)$, and this medium was used to study the effect of culture conditions such as temperature, $\mathrm{pH}$, agitation, and aeration by employing a one-factor-at-a-time method. For the substrate optimization studies, rice bran, wheat bran, and the concentration of sulfuric acid were all selected as variable factors, while L-glutamic acid $(10.5 \%)$, yeast extract $(1.32 \%)$, citric acid $(1 \%), \mathrm{KH}_{2} \mathrm{PO}_{4}(0.1 \%)$, and $\mathrm{MgSO}_{4} \cdot 7 \mathrm{H}_{2} \mathrm{O}(0.1 \%)$ levels were kept constant. All experiments were performed in a $2.5 \mathrm{~L}$ fermentor (KF-2.5L; Ko-biotech Co., Incheon, Korea) containing $1 \mathrm{~L}$ medium at an incubation period of $24 \mathrm{~h}$. Fed-batch fermentations were performed by periodically supplementing (every $12 \mathrm{~h}$ ) glutamate and citric acid $(50 \mathrm{~mL}$ of each substrate at the concentration of $50 \mathrm{~g} / \mathrm{L}$ and $5 \mathrm{~g} / \mathrm{L}$ ) for $60 \mathrm{~h}$.

\subsection{Optimization Studies Using RSM}

RSM was performed using a central composite design (CCD) to investigate the optimal combination and the key interactions of independent variables in the context of $\gamma$-PGA production (Table 1). RSM is 
a combination of statistical methods that is used for selecting the optimum experimental conditions that require the minimum number of experiments.

$$
x_{i}=\frac{X_{i}-X_{0}}{\Delta X_{i}}
$$

The experimental variables were coded according to the above equation, where $X_{i}$ is the actual value of the independent variable, $X_{0}$ is the independent variable value at the center point, $\Delta X_{i}$ is the step change value, and $x_{i}$ is the coded value of each independent variable.

Table 1. Variables and experimental design levels used in the central composite design for rice bran and wheat bran.

\begin{tabular}{ccccccc}
\hline \multirow{2}{*}{$\begin{array}{c}\text { Independent } \\
\text { Variables }\end{array}$} & \multirow{2}{*}{$\begin{array}{c}\text { Coded } \\
\text { Symbols }\end{array}$} & $\mathbf{- 1 . 4 1 4}$ & $\mathbf{- 1}$ & $\mathbf{0}$ & $\mathbf{1}$ & $\mathbf{1 . 4 1 4}$ \\
\cline { 3 - 7 } & $X_{1}$ & 1.7 & 10 & 30 & 50 & 58.3 \\
Bran $(\mathrm{g} / \mathrm{L})$ & $X_{2}$ & 0.017 & 0.1 & 0.3 & 0.5 & 0.583 \\
$\mathrm{H}_{2} \mathrm{SO}_{4}(\%, \mathrm{v} / \mathrm{v})$ & & & & &
\end{tabular}

As shown in Table 2, to investigate the nature of the response surface in the optimum region, a $2^{3}$ factorial CCD with eight axial points and six center points was used, and this resulted in a total of 14 experiments. To optimize the production of $\gamma$-PGA, the following second-order polynomial equation was used for statistical analysis.

$$
y=b_{1}+\sum b_{i} x_{i} \sum b_{i j} x_{i} x_{j}+\sum b_{i i} x_{i}^{2}
$$

where $y$ is a predicted value, $b_{0}$ is a constant, $b_{i}, b_{i i}$, and $b_{i j}$ are first-order coefficients, second-order coefficients, and interaction coefficients, respectively, $x_{i}$ is the independent variable of $i, x_{i} x_{j}$ is the interaction between independent variables, and $x_{i}^{2}$ is the second order coefficient. The quality of fit of the model equation was described by the coefficient of determination, $R^{2}$, and the significance of statistics was determined using an F-test. The significance of the regression coefficients was investigated by t-test. The computer software used was Design-Expert version 9.0.0 by Stat-Ease, Inc. (USA). The combination of different optimized variables that yielded the maximum response was determined in an attempt to verify the validity of the model.

Table 2. Central composite design (CCD) of two independent variables.

\begin{tabular}{ccc}
\hline \multirow{2}{*}{ Run No. } & \multicolumn{2}{c}{ Coded Variable Level } \\
\cline { 2 - 3 } & $\boldsymbol{X}_{\mathbf{1}}$ & $\boldsymbol{X}_{\mathbf{2}}$ \\
\hline 1 & -1 & -1 \\
2 & 1 & -1 \\
3 & -1 & 1 \\
4 & 1 & 1 \\
5 & -1.414 & 0 \\
6 & 1.414 & 0 \\
7 & 0 & -1.414 \\
8 & 0 & 1.414 \\
9 & 0 & 0 \\
10 & 0 & 0 \\
11 & 0 & 0 \\
12 & 0 & 0 \\
13 & 0 & 0 \\
14 & 0 & 0 \\
\hline
\end{tabular}




\subsection{Analytical Methods}

Cell growth was monitored by measuring the optical density using a UV-1600 spectrophotometer (Shimadzu Co., Tokyo, Japan) at $660 \mathrm{~nm}$, and this value was then converted to dry cell weight (DCW, g/L) based on the liner relation of DCW and optical density. The viscosity of the culture broth containing $\gamma$-PGA was measured using a DV2T digital rheometer equipped with a spindle CP-42 (Brookfield, Middleboro, MA, USA) at $25^{\circ} \mathrm{C}$ and $10 \mathrm{rpm}$ for $30 \mathrm{~s}$. The measured viscosity was corrected using silicon oil standards $\left(44.8 \mathrm{cP}\right.$ and $496 \mathrm{cP}$ at $\left.25^{\circ} \mathrm{C}\right) . \gamma$-PGA was determined by alcohol precipitation according to the modified method reported by Kunioka and Goto [16]. The fermentation broth was diluted and centrifuged at $32,000 \times g$ for $30 \mathrm{~min}$. The resulting supernatant was poured into four volumes of cold ethanol. The precipitate was collected and washed with ethanol, and it was then dissolved and dialyzed against deionized water overnight. The dialyzed solution was centrifuged, and the supernatant was lyophilized to prepare pure $\gamma$-PGA.

\subsection{Thin Layer Chromatograph (TLC)}

Thin layer chromatography (TLC) was performed to identify hydrolysis products of $\gamma$-PGA. Using a $50 \mathrm{~mL}$ vial, purified $\gamma$-PGA was dissolved in $6 \mathrm{M} \mathrm{HCl}$ to a concentration of $1 \mathrm{~g} / \mathrm{L}$ and hydrolyzed at $110^{\circ} \mathrm{C}$ for $1 \mathrm{~h}$. Hydrolysis specimens $(2 \mu \mathrm{L})$ were added to a silica gel TLC plate (Silica gel $60 \mathrm{~F} 254$, $10 \times 10 \mathrm{~cm}$ ) purchased from Merck (Darmstadt, Germany). $n$-Butanol: acetic acid: $\mathrm{H}_{2} \mathrm{O}(3: 1: 1, \mathrm{v} / \mathrm{v} / \mathrm{v})$ and $96 \%$ ethanol: $\mathrm{H}_{2} \mathrm{O}(63: 37, \mathrm{v} / \mathrm{v})$ were created for use as the primary developer. After deployment as the primary developer, the deployment of the secondary developer was completed, and a $0.2 \%$ ninhydrin acetic acid solution was identified. This solution was dried for $10 \mathrm{~min}$ at $110^{\circ} \mathrm{C}$ to identify visible hydrolysis products [17].

\section{Results and Discussion}

\subsection{Optimization Using One-Factor-at-a-Time}

To identify the temperature effect and to determine the optimum temperature for $\gamma$-PGA production, five experiments were conducted at various temperatures ranging from 27 to $47{ }^{\circ} \mathrm{C}$ at $5{ }^{\circ} \mathrm{C}$ increments (Figure $1 \mathrm{a}-\mathrm{c}$ ). As shown in the figure, at $37^{\circ} \mathrm{C}$, we observed maximum $\gamma$-PGA production $(100.7 \mathrm{~g} / \mathrm{L})$, viscosity $(483.2 \mathrm{cP})$, and dry cell mass $(3.4 \mathrm{~g} / \mathrm{L})$, and similar values were obtained at $32{ }^{\circ} \mathrm{C}(97.1 \mathrm{~g} / \mathrm{L}, 433.1 \mathrm{cP}$, and $3.4 \mathrm{~g} / \mathrm{L})$. Additionally, the production of $\gamma$-PGA at $42{ }^{\circ} \mathrm{C}$ and $47^{\circ} \mathrm{C}$ appeared very rapid at the start of the reaction; however, the final yield and viscosity dropped to low values. This may have been due to rapid cell growth at $42^{\circ} \mathrm{C}$ and $47^{\circ} \mathrm{C}$ during the early stages and a subsequent lethal effect at the later stages of fermentation. Cheng et al. [18] reported $30^{\circ} \mathrm{C}$ as the optimal temperature for B. licheniformis A35. Unlike the other studies, Kubota et al. [19] used $42{ }^{\circ} \mathrm{C}$ as the optimum temperature for B. subtilis F-2-01. In the present study, $37^{\circ} \mathrm{C}$ was selected as the optimum temperature for use in further studies.

To determine the optimum $\mathrm{pH}$ for $\gamma$-PGA production, five experiments were conducted at different initial $\mathrm{pH}$ that included control (not adjusted), 5, 6, 7, and 8. As shown in Figure 2a-c, yield, viscosity, and dry cell mass were higher at $100.7 \mathrm{~g} / \mathrm{L}, 483.2 \mathrm{cP}$, and $3.4 \mathrm{~g} / \mathrm{L}$, respectively, at the control pH. These results were similar to those obtained at $\mathrm{pH} 7$, and they were much higher than the results obtained at pH 5 and pH 8 (83.6 g/L). The pH change in the control was not shown in the figure; however, we observed that the initial $\mathrm{pH}$ of the control medium was 6.75, and it first decreased to 5.92 and then gradually increased after $18 \mathrm{~h}$. In the $\mathrm{pH} 5$ experiment, the yield of $\gamma$-PGA, viscosity, and dry cell mass were significantly reduced, indicating that, in acidic environments, cell growth was impaired and $\gamma$-PGA biosynthesis was not accomplished properly. Cromwick et al. [20] reported similar results in regard to $\mathrm{pH}$, where they obtained the highest $\gamma$-PGA yield at 6.5 , and they suggested that, at this $\mathrm{pH}$, the molecular weight and the substrate consumption were also increased. Zanuy et al. [21] demonstrated that the carboxyl group of $\gamma$-PGA possessed different structures of exposed anionic polymers depending on $\mathrm{pH}$ changes within the solution. Therefore, it is assumed that structural 
changes within the polymer that result from changes in the $\mathrm{pH}$ will affect the viscosity. Our results suggest that there is no need to adjust the $\mathrm{pH}$ of the medium to allow for improved $\gamma$-PGA synthesis.
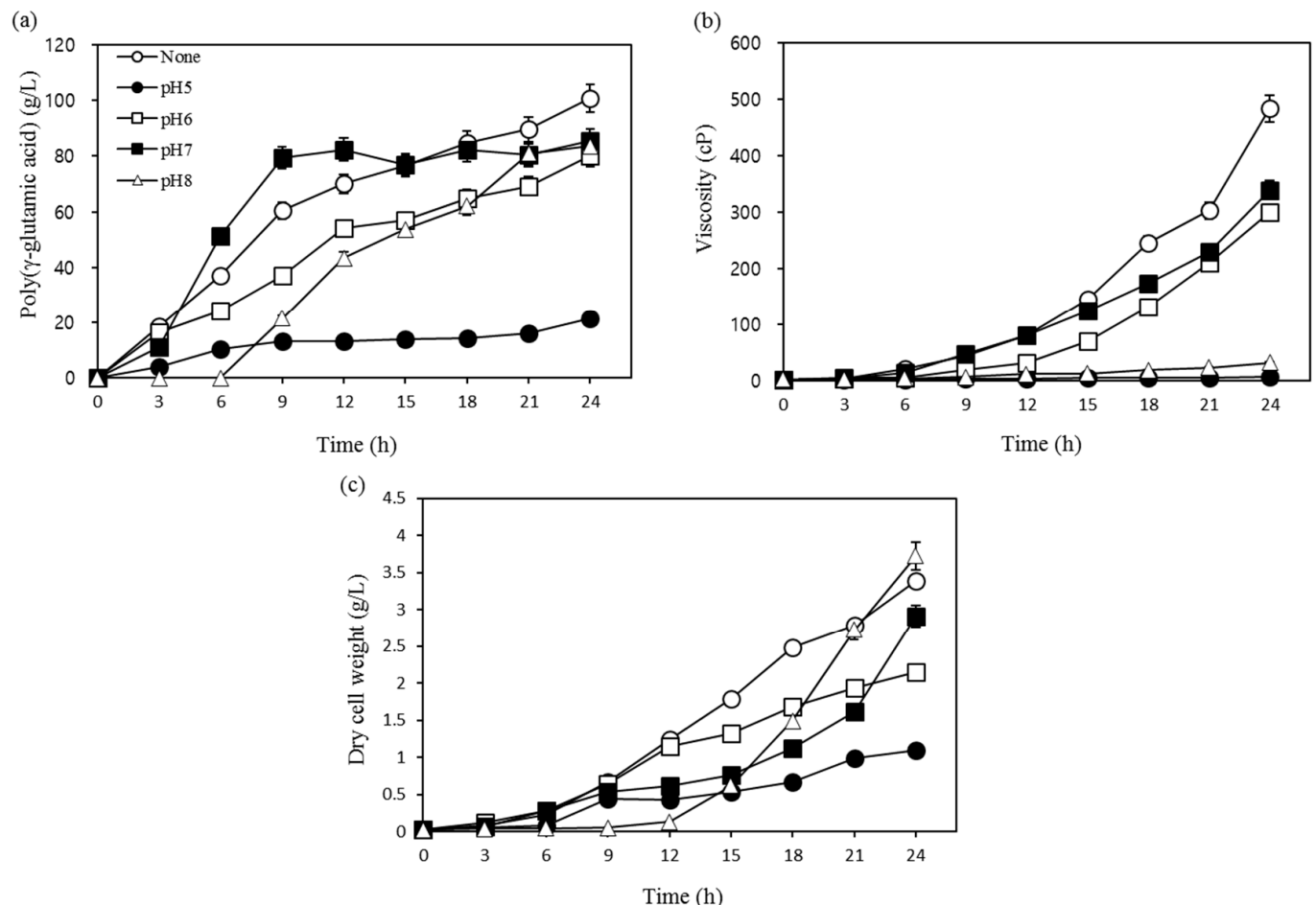

Figure 2. Effects of $\mathrm{pH}$ on (a) poly-( $\gamma$-glutamic acid) production, (b) viscosity, and (c) dry cell weight.

To determine the effect of aeration rate on $\gamma$-PGA production, we utilized Bacillus sp. FBL-2. This experiment was conducted using six variables that included control (no air), $0.25 \mathrm{vvm}, 0.5 \mathrm{vvm}$, $0.75 \mathrm{vvm}, 1.00 \mathrm{vvm}, 1.25 \mathrm{vvm}$, and $1.5 \mathrm{vvm}$, and it was performed using a $2.5 \mathrm{~L}$ fermentor under constant temperature and agitation $\left(37^{\circ} \mathrm{C}\right.$ and $200 \mathrm{rpm}$, respectively) (Figure $3 \mathrm{a}-\mathrm{c}$ ). A high $\gamma$-PGA yield $(70.9 \mathrm{~g} / \mathrm{L})$, viscosity $(39.9 \mathrm{cP})$, and dry cell mass $(1.6 \mathrm{~g} / \mathrm{L})$ were observed under conditions of $1.5 \mathrm{vvm}$ air sparging, and these values were 2.8 times higher than those obtained under control conditions, where $\gamma$-PGA yield, viscosity, and dry cell mass were $27.1 \mathrm{~g} / \mathrm{L}, 6.7 \mathrm{cP}$, and $0.2 \mathrm{~g} / \mathrm{L}$, respectively. We observed that yield, viscosity, and dry cell mass all gradually increased as the aeration rate increased from $0.5 \mathrm{vvm}$ to $1.5 \mathrm{vvm}$. It is likely that the high aeration promoted cell growth to improve the production of $\gamma$-PGA. Additionally, studies by Cromwick [20] and Bajaj and Singhal [22] reported that increased oxygen supply improved cell growth and ultimately doubled the maximum dried cell mass while depleting carbon sources more rapidly to provide enhanced production of $\gamma$-PGA. The results of this study confirmed that increased oxygen supply improved production yields, highlighting the role of oxygen supply as an important factor in the production of $\gamma$-PGA. Additionally, these results confirmed that a $1.5 \mathrm{vvm}$ aeration rate is optimal for $\gamma$-PGA fermentation.

To determine the optimum agitation speed for the production of $\gamma$-PGA by Bacillus sp. FBL-2, four variable speeds $(200,250,300$, and $350 \mathrm{rpm})$ were screened (Figure $4 \mathrm{a}-\mathrm{c})$. For all the tested agitation speeds, the highest $\gamma$-PGA production $(100.7 \mathrm{~g} / \mathrm{L})$, viscosity $(483.2 \mathrm{cP})$, and dry cell mass $(3.4 \mathrm{~g} / \mathrm{L})$ were obtained at $350 \mathrm{rpm}$, and the lowest $\gamma$-PGA production yields $(70.9 \mathrm{~g} / \mathrm{L})$, viscosity $(37.5 \mathrm{cP})$, and dry cell masses $(1.7 \mathrm{~g} / \mathrm{L})$ were observed at $200 \mathrm{rpm}$. We observed that, as the viscosity increased exponentially, the amount of dry cell mass and the $\gamma$-PGA yield also increased proportionally as the stirrer speed was increased. Our results are in agreement with those of previous investigations that indicated that increased agitation resulted in enhanced $\gamma$-PGA production [22]. According to the studies by Cromwick et al. [20] and Bajaj and Singhal [22], a higher viscosity within the fermented solution resulted in a decrease in the efficiency of oxygen transmission, ultimately affecting the transfer of nutrients and the distribution of air and oxygen. Therefore, it is likely that increasing the stirring speed 
resulted in a more even oxygen supply, ultimately increasing cell growth, viscosity, and the production of $\gamma$-PGA. Based on the results of this study, it was determined that the stirring speed is an essential parameter for the production of $\gamma$-PGA, and we selected agitation at $350 \mathrm{rpm}$ for further studies.
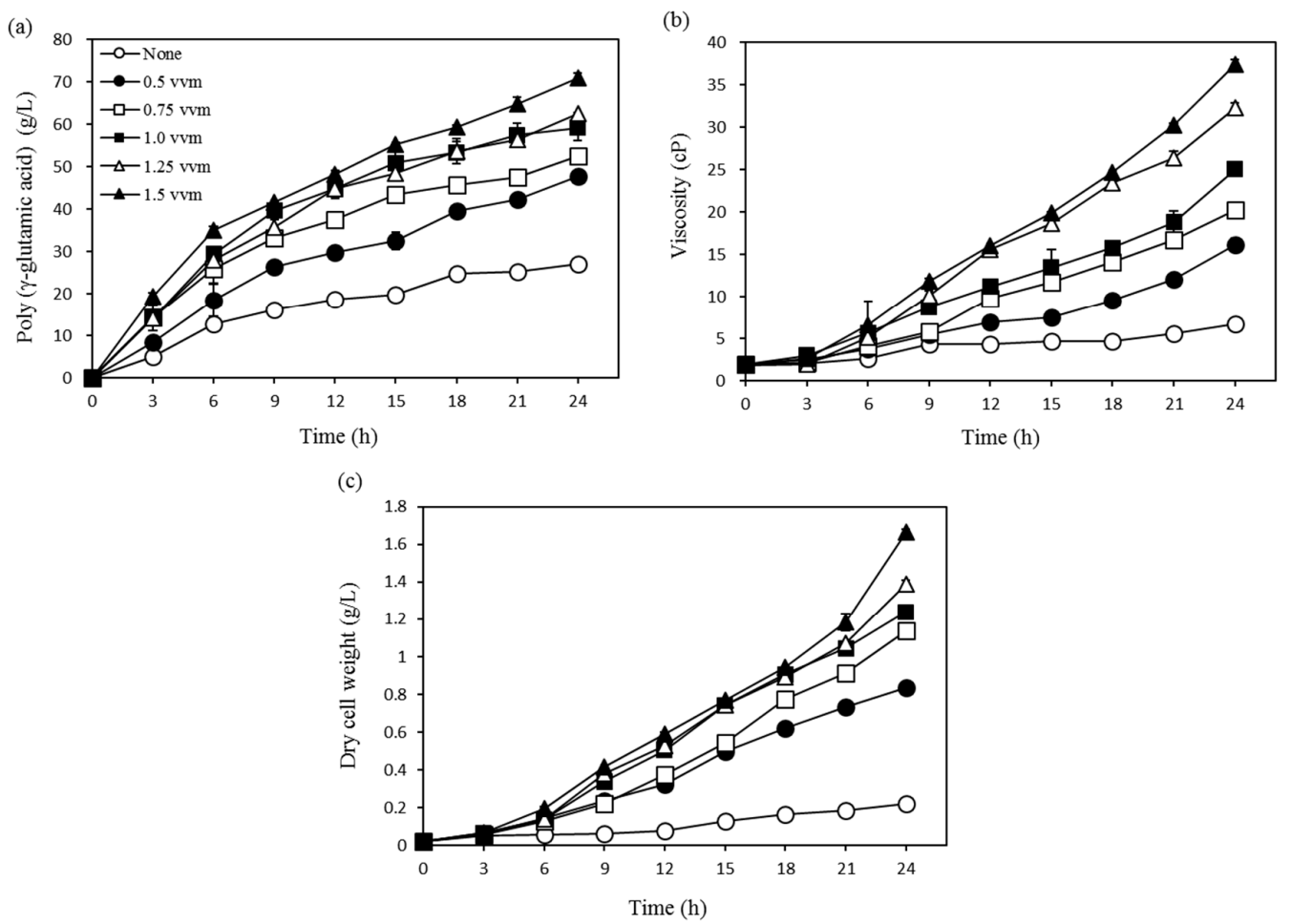

Figure 3. Effects of aeration rate on (a) poly-( $\gamma$-glutamic acid) production, (b) viscosity, and (c) dry cell weight.
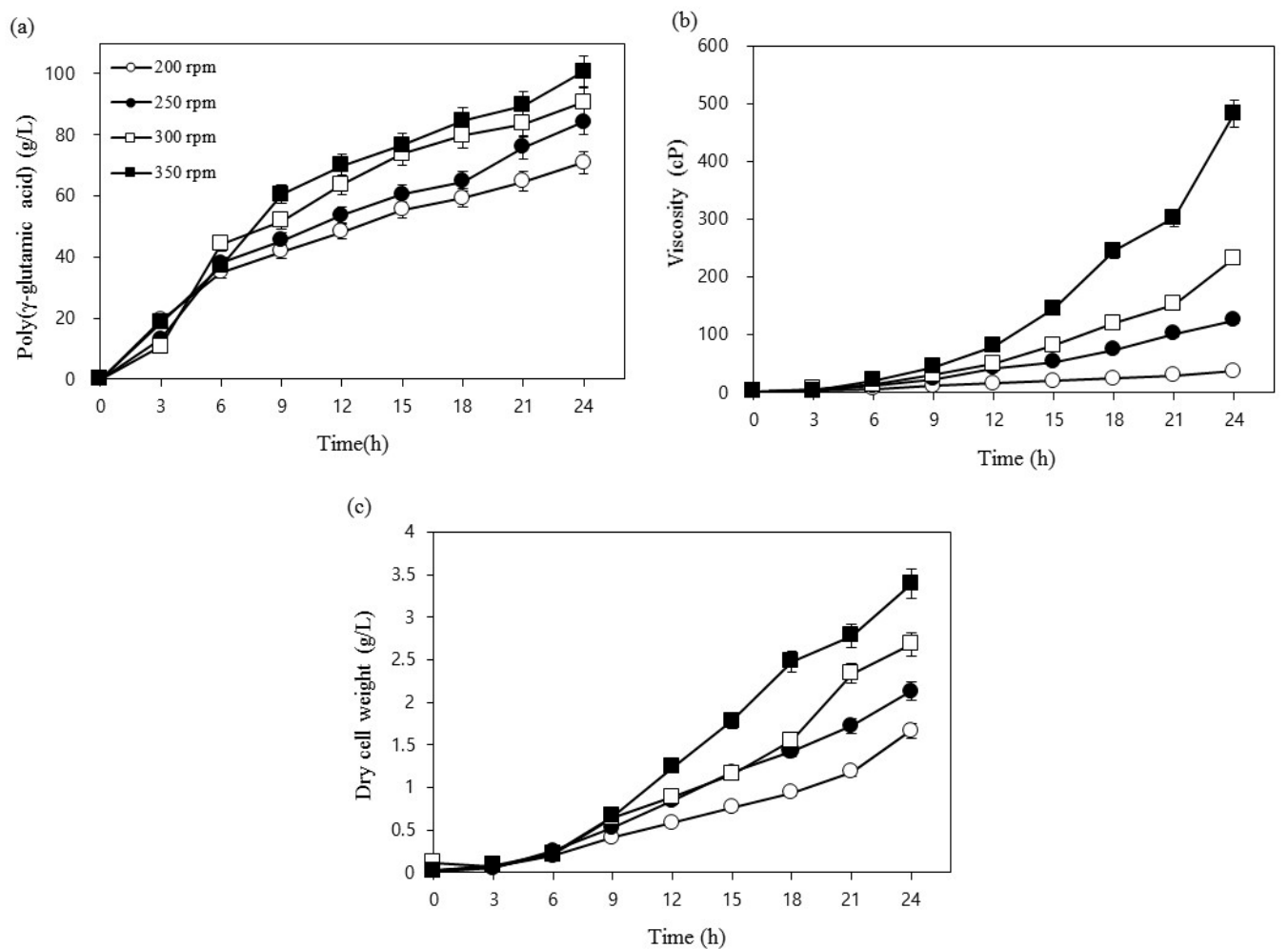

Figure 4. Effects of agitation speed on (a) poly ( $\gamma$-glutamic acid) production, (b) viscosity, (c) dry cell weight. 


\subsection{Fed-Batch Fermentation}

To overcome the shortcomings of batch fermentation that result from such events as nutrient depletion due to microbial metabolism, fed-batch fermentation was conducted under previously optimized culture conditions. Based on the results of the preliminary experiments, substrates were added every $12 \mathrm{~h}$, and the fermentation time was increased up to $60 \mathrm{~h}$. Samples were collected every $6 \mathrm{~h}$ to assess the amount of $\gamma$-PGA and the residual substrate concentration (Figure 5). As shown in the figure, a maximum $\gamma$-PGA production of $175.9 \mathrm{~g} / \mathrm{L}$ was achieved after $60 \mathrm{~h}$ of incubation, and $38.3 \mathrm{~g} / \mathrm{L}$ and $2.87 \mathrm{~g} / \mathrm{L}$ of L-glutamic acid and citric acid, respectively, were unused and existed as residuals. L-glutamic acid and citric acid are important precursors for the production of $\gamma$-PGA; however, it is assumed that the addition of very high substrate concentrations inhibits cell growth at or above the concentration limit and that the length of the molecular chain of $\gamma$-PGA is dependent upon the substrate concentration, as short chain lengths result in low viscosity. Poly- $(\gamma$-glutamic acid $)$ production obtained from each optimization step is presented in Table 3. As indicated in the table, the resulting concentration of $\gamma$-PGA in the present study was very high compared to that detailed in previous reports. Yoon et al. [23] achieved only $35 \mathrm{~g} / \mathrm{L}$ of $\gamma$-PGA with $1 \mathrm{~g} / \mathrm{L} / \mathrm{h}$ productivity using optimized fed-batch fermentation by Bacillus licheniformis. Jeong et al. [24] and Zhang et al. [9] also reported similar low production of $\gamma$-PGA using Bacillus subtilis RKY3 and an optimized fermentation process.
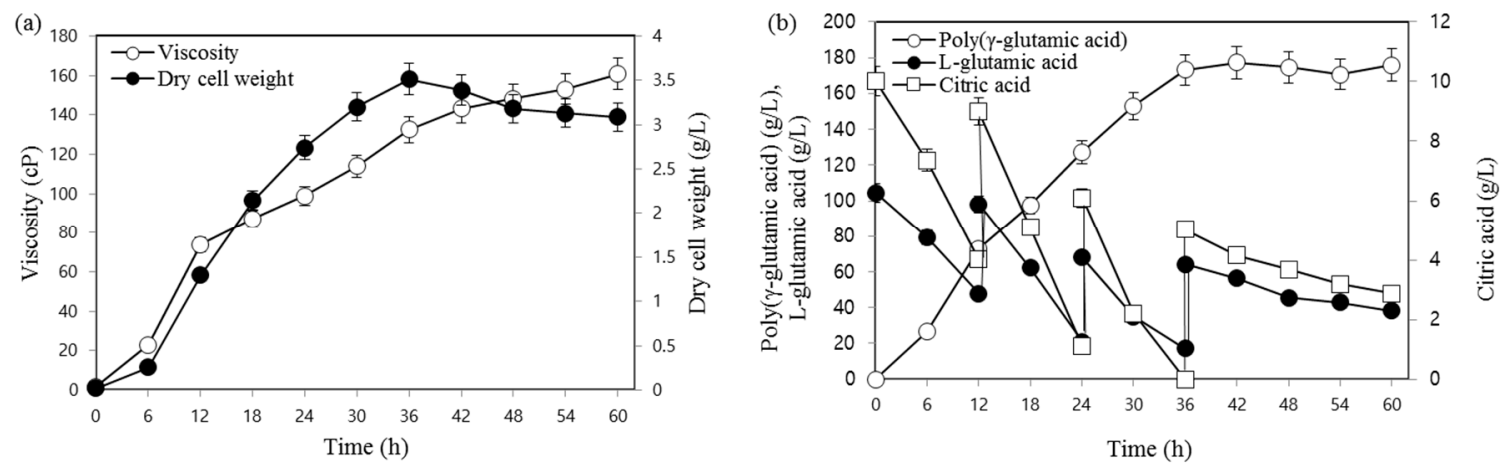

Figure 5. Poly-( $\gamma$-glutamic acid) production following the addition of L-glutamic acid, citric acid, and yeast extract. (a) Viscosity and dry cell weight; (b) poly( $\gamma$-glutamic acid) production and consumption of L-glutamic acid and citric acid.

Table 3. Poly-( $\gamma$-glutamic acid $)$ production obtained from each optimization step.

\begin{tabular}{|c|c|c|c|c|}
\hline Optimization Step & $\begin{array}{c}\text { Dry Cell } \\
\text { Weight (g/L) }\end{array}$ & $\begin{array}{l}\text { Viscosity } \\
\text { (cP) }\end{array}$ & $\begin{array}{l}\text { Poly- }(\gamma \text {-glutamic acid }) \\
\text { Production }(g / L)\end{array}$ & $\begin{array}{l}\text { Poly-( } \gamma \text {-glutamic acid) } \\
\text { Production (Fold) }\end{array}$ \\
\hline Before optimization * & 0.2 & 6.7 & 27.1 & 1.0 \\
\hline $\begin{array}{l}\text { After fermentor } \\
\text { optimization ** }\end{array}$ & 3.4 & 483.2 & 100.7 & 3.7 \\
\hline $\begin{array}{l}\text { After fed-batch } \\
\text { fermentation *** }\end{array}$ & 3.1 & 160.9 & 175.9 & 6.5 \\
\hline
\end{tabular}

*: The fermentation was performed using a $2.5 \mathrm{~L}$ fermentor containing $1 \mathrm{~L}$ of fermentation medium at $200 \mathrm{rpm}$ and $37^{\circ} \mathrm{C}$. **: The fermentation was performed using a $2.5 \mathrm{~L}$ fermentor containing $1 \mathrm{~L}$ of fermentation medium at $1.5 \mathrm{vvm}, 350 \mathrm{rpm}$, and $37^{\circ} \mathrm{C}$. ${ }^{* * *}$ : The fermentation was performed using a $2.5 \mathrm{~L}$ fermentor containing $1 \mathrm{~L}$ of fermentation medium at $1.5 \mathrm{vvm}, 350 \mathrm{rpm}$, and $37^{\circ} \mathrm{C}$.

\section{3. $\gamma$-PGA Production Using Agricultural Byproducts}

For the production of $\gamma$-PGA using agricultural byproducts, these byproducts must first be hydrolyzed into simple fermentable sugars. Rice bran [composition in percentages (\%): moisture, 5.4; fiber, 30.17; carbohydrate, 52.5; protein, 17.5; ash, 5] and wheat bran [composition in percentages (\%): moisture, 8.4; fiber, 33.5; carbohydrate, 62.5 ; protein, 12.5 ; ash, 6 ] were selected as agricultural byproducts and hydrolyzed using dilute $\mathrm{H}_{2} \mathrm{SO}_{4}$. To determine the optimal concentrations of rice/wheat 
bran and $\mathrm{H}_{2} \mathrm{SO}_{4}$, a central composite design method was used for a total of 14 experiments that included six center points to estimate the error of the experiment. The experimental results were then derived through the use of multiple regression analyses (Table $4 a$ and $b$ ). A second-order polynomial equation was obtained to predict the production of $\gamma$-PGA.

$$
y=-2.74475+0.979296 x_{1}+32.09556 x_{2}-0.014965 x_{1} x_{2}-0.01282 x_{1}{ }^{2}-39.8736 x_{2}^{2}
$$

In the above polynomial equation, y represents the expected yield of $\gamma$-PGA $(\mathrm{g} / \mathrm{L}), x_{1}$ represents rice bran, and $x_{2}$ is the coded value of $\mathrm{H}_{2} \mathrm{SO}_{4}$.

$$
y=-3.11752+0.978556 x_{1}+24.6798 x_{2}-0.14245 x_{1} x_{2}-0.01664 x_{1}^{2}-31.823 x_{2}^{2}
$$

In the above polynomial equation, y represents the expected production of $\gamma$-PGA (g/L), $x_{1}$ represents the wheat bran, and $x_{2}$ is the coded value of $\mathrm{H}_{2} \mathrm{SO}_{4}$.

Table 4. Analysis of variance (ANOVA) for the response surface quadratic model for poly-( $\gamma$-glutamic

\begin{tabular}{|c|c|c|c|c|c|c|}
\hline & Source & $\begin{array}{l}\text { Sum of } \\
\text { Squares }\end{array}$ & $\begin{array}{l}\text { Degree of } \\
\text { Freedom }\end{array}$ & $\begin{array}{l}\text { Mean } \\
\text { Square }\end{array}$ & $F$-Value & $\begin{array}{l}p \text {-Value } \\
\text { Prob }>F\end{array}$ \\
\hline \multirow[t]{6}{*}{ (a) } & Model & 375.7881 & 5 & 75.15762 & 37.56641 & $<0.0001$ \\
\hline & Residual & 16.00528 & 8 & 2.00066 & & \\
\hline & Lack of Fit & 13.1064 & 3 & 4.3688 & 7.53532 & 0.0265 \\
\hline & Pure Error & 2.898882 & 5 & 0.579776 & & \\
\hline & Corrected Total & 391.7934 & 13 & & & \\
\hline & \multicolumn{6}{|c|}{$R^{2}=0.9591 ;$ adjusted $R^{2}=0.9336 ;$ adequately precision $=17.625 ; \mathrm{CV}=8.11 \%$} \\
\hline \multirow[t]{6}{*}{ (b) } & Model & 346.0666 & 5 & 69.213397 & 29.51582 & $<0.0001$ \\
\hline & Residual & 18.75965 & 8 & 2.344356691 & & \\
\hline & Lack of Fit & 17.97731 & 3 & 5.992436649 & 38.29799 & 0.0007 \\
\hline & Pure Error & 0.782344 & 5 & 0.156468716 & & \\
\hline & Corrected Total & 364.8563 & 13 & & & \\
\hline & $R^{2}=0.948$ & isted $R$ & 164; ade & ly precisior & $.053 ; \mathrm{CV}$ & $33 \%$ \\
\hline
\end{tabular}
acid) production by Bacillus sp. FBL-2. (a) Rice bran; (b) wheat bran.

The results of the ANOVA analysis indicated that the $F$-value of the regression formula in the experimental model was statistically significant, as the $p$-value was less than 0.0001 for rice bran and wheat bran (37.5664 and 29.51582, respectively) (Table 4a and b). The coefficients of determination for this model were 0.9591 and 0.9485 , respectively, indicating that the regression formula is highly useful. The predicted values for the production of $\gamma$-PGA according to this model formula were $95.91 \%$ and $94.85 \%$, respectively. Based on this, the secondary polynomial obtained by multiple regression analyses could be characterized as possessing a high level of confidence, and the level at which $\gamma$-PGA production was predicted was within the range of each variable.

Based on the regression equation, the three-dimensional response surface graph visualizes the interaction of important factors and the correlation between the production volume of $\gamma$-PGA and the concentration. As shown in Figure 6, the two response surface curves exhibited a convex shape and outlined the position of the optimum conditions. The optimal levels for each factor as calculated by the regression formula were $38.6 \mathrm{~g} / \mathrm{L}$ and $0.42 \% \mathrm{H}_{2} \mathrm{SO}_{4}$ for rice bran and $28.0 \mathrm{~g} / \mathrm{L}$ and $0.32 \% \mathrm{H}_{2} \mathrm{SO}_{4}$ for wheat bran. For the predicted response at the optimum level, $\gamma$-PGA production was established using centralization planning experiments that incorporated levels of rice bran and wheat bran at $22.64 \mathrm{~g} / \mathrm{L}$ and $14.6 \mathrm{~g} / \mathrm{L}$, respectively. $\gamma$-PGA synthesis was improved five-fold by RSM using Bacillus licheniformis NCIM 2324 [25]. RSM provides an effective means for optimizing PGA production. 
(a)

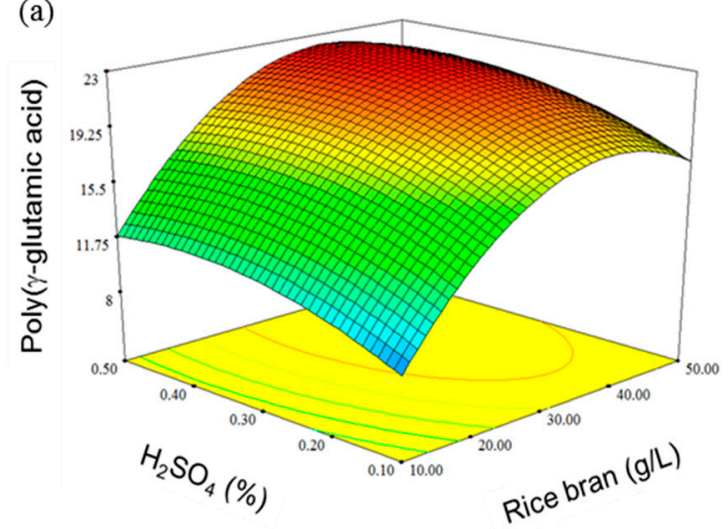

(b)

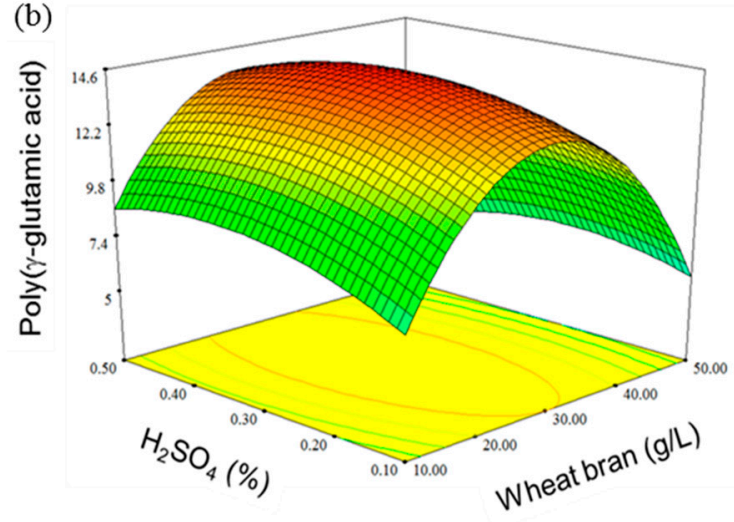

Figure 6. Response surface and contour plots of poly-( $\gamma$-glutamic acid) production by Bacillus sp. FBL-2. (a) rice bran; (b) wheat bran.

\subsection{Verification of the Optimal Model}

The optimization model was verified by experimenting with optimized conditions of two factors important for the production of $\gamma$-PGA. Bacillus sp. FBL-2 was inoculated with rice bran or wheat bran $\left(38.6 \mathrm{~g} / \mathrm{L}, 0.42 \% \mathrm{H}_{2} \mathrm{SO}_{4}\right.$ and $\left.28 \mathrm{~g} / \mathrm{L}, 0.32 \% \mathrm{H}_{2} \mathrm{SO}_{4}\right)$ under previously optimized culture conditions. Rice bran medium produced higher $\gamma$-PGA $(47.6 \mathrm{~g} / \mathrm{L})$, viscosity $(21.4 \mathrm{cP})$, and dry cell mass $(0.46 \mathrm{~g} / \mathrm{L})$ compared to those produced using the wheat bran medium $[\gamma-\mathrm{PGA}(36.4 \mathrm{~g} / \mathrm{L})$, viscosity $(8.2 \mathrm{cP})$, and dry cell mass $(0.44 \mathrm{~g} / \mathrm{L})]$. The yields of $\gamma$-PGA from rice bran and wheat bran as predicted by the regression formula were $22.64 \mathrm{~g} / \mathrm{L}$ and $14.6 \mathrm{~g} / \mathrm{L}$, respectively. The experimental values, however, were 2.1 times higher than the predicted yields. In the present study, the possibility of utilizing economically cheap substitutes in place of the expensive medium components was explored. For example, simply replacing sucrose with rice bran could lower production costs on average by a factor of 10. Similarly, the replacement of the more commonly used and expensive precursors with the more inexpensive and available substitutes would also result in a considerable reduction in production costs. Therefore, the results of our experiments suggest that agricultural byproducts such as rice bran and wheat bran could provide suitable substitutes for the effective economization of $\gamma$-PGA production.

\subsection{Analysis of Hydrolysis Products of $\gamma-P G A$}

Thin layer chromatography (TLC) was used to verify the hydrolysis of viscous polymers produced under optimal conditions. The peptides that comprise $\gamma$-PGA are connected in a $\gamma$-combination. After hydrolysis, an analysis of $\gamma$-PGA hydrolysis products revealed that the $\mathrm{R}_{\mathrm{f}}$ value of the hydrolysis products and the $R_{\mathrm{f}}$ value of glutamic acid were indicative of the presence of a viscous polymer that was identified as $\gamma$-PGA, a polyamino acid composed of glutamic acid (Figure 7). 


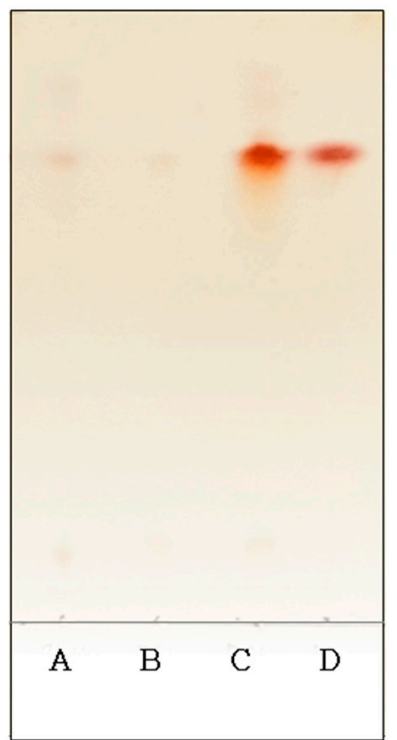

Figure 7. Thin layer chromatography of poly-( $\gamma$-glutamic acid $)$ hydrolysate. Lane A, precipitated poly-( $\gamma$-glutamic acid); Lane B, after addition of $\mathrm{HCl}$ on poly-( $\gamma$-glutamic acid); Lane $\mathrm{C}$, after addition of $\mathrm{HCl}$ on poly- $(\gamma$-glutamic acid $)$ and heat treatment at $110^{\circ} \mathrm{C}$ for $30 \mathrm{~min}$; Lane D: glutamic acid standard.

Author Contributions: D.-Y.S. performed the experimental work; L.V.R. analyzed the data and wrote the manuscript; D.C. reviewed the manuscript; Y.-J.W. designed the experimental work and reviewed and edited the manuscript.

Funding: This research was supported by the Basic Science Research Program through the National Research Foundation of Korea (NRF) and funded by the Ministry of Education (2017R1D1A1B03032906).

Conflicts of Interest: The authors declare no conflict of interest.

\section{References}

1. Kubota, H.; Nambu, Y.; Endo, T. Convenient and quantitative esterification of poly( $\gamma$-glutamic acid $)$ produced by microorganism. J. Polym. Sci. Part A Polym. Chem. 1993, 31, 2877-2878. [CrossRef]

2. Shih, I.L.; Van, Y.T. The production of poly-(gamma-glutamic acid) from microorganisms and its various applications. Bioresour. Technol. 2001, 79, 207-222. [CrossRef]

3. Richard, A.; Margaritis, A. Rheology, oxygen transfer, and molecular weight characteristics of poly(glutamic acid) fermentation by Bacillus subtilis. Biotechnol. Bioeng. 2003, 82, 299-305. [CrossRef] [PubMed]

4. Hsueh, Y.H.; Huang, K.Y.; Kunene, S.C.; Lee, T.Y. Poly- $\gamma$-glutamic acid synthesis, gene regulation, phylogenetic relationships, and role in fermentation. Int. J. Mol. Sci. 2017, 18, 2644. [CrossRef]

5. Kunioka, M. Biosynthesis of poly $(\gamma$-glutamic acid) from L-glutamine, citric acid, and ammonium sulfate in Bacillus subtilis IFO3335. Appl. Microbiol. Biotechnol. 1995, 44, 501-506. [CrossRef]

6. Cao, M.; Geng, W.; Liu, L.; Song, C.; Xie, H.; Guo, W.; Jin, Y.; Wang, S. Glutamic acid independent production of poly- $\gamma$-glutamic acid by Bacillus amyloliquefaciens LL3 and cloning of pgsBCA genes. Bioresour. Technol. 2011, 102, 4251-4257. [CrossRef] [PubMed]

7. Ogunleye, A.; Bhat, A.; Irorere, V.U.; Hill, D.; Williams, C.; Radecka, I. Poly-c-glutamic acid: Production, properties and applications. Microbiology 2015, 161, 1-17. [CrossRef] [PubMed]

8. Tang, B.; Lei, P.; Xu, Z.; Jiang, Y.; Xu, Z.; Liang, J.; Feng, X.; Xu, H. Highly efficient rice straw utilization for poly-( $\gamma$-glutamic acid) production by Bacillus subtilis NX-2. Bioresour. Technol. 2015, 193, 370-376. [CrossRef]

9. Zhang, D.; Feng, X.; Zhou, Z.; Zhang, Y.; Xu, H. Economical production of poly(cglutamic acid) using untreated cane molasses and monosodium glutamate waste liquor by Bacillus subtilis NX-2. Bioresour. Technol. 2012, 114, 583-588. [CrossRef]

10. Xiong, C.; Shouwen, C.; Ming, S.; Ziniu, Y. Medium optimization by response surface methodology for poly- $\gamma$-glutamic acid production using dairy manure as the basis of a solid substrate. Appl. Microbiol. Biotechnol. 2005, 69, 390-396. [CrossRef] 
11. Anju, A.J.; Bnod, P.; Pandey, A. Production and characterization of PGA from renewable resources. J. Exper. Biol. 2017, 55, 405-410.

12. Juliano, B.O.; Hicks, P.A. Rice functional properties and rice food products. Food Rev. Int. 1996, 12, 71-103. [CrossRef]

13. Cicero, A.F.; Gaddi, A. rice bran oil and gamma-oryzanol in the treatment of hyperlipoproteinaemias and other conditions. Phytother. Res. 2001, 15, 277-289. [CrossRef] [PubMed]

14. Barnes, P.J. Wheat in Milling and Baking. In Cereal Science and Technology; Aberdeen University Press: Aberdeen, UK, 1989; pp. 367-407.

15. Kaewjumpola, G.; Oruna-Conchab, M.J.; Niranjanb, K.; Thawornchinsombuta, S. The production of hydrolysates from industrially defatted rice bran and its surface image changes during extraction. J. Sci. Food Agric. 2017, 98, 3290-3298. [CrossRef]

16. Kunioka, M.; Goto, A. Biosynthesis of poly ( $\gamma$-glutamic acid) from L-glutamic acid, citric acid, and ammonium sulfate in Bacillus subtilis IFO3335. Appl. Microbiol. Biotechnol. 1994, 40, 867-872. [CrossRef]

17. Shin, I.L.; Van, V.T.; Yeh, L.C.; Lin, H.G.; Chan, Y.N. Production of a bio-polymer flocculant from Bacillus licheniformis and its flocculation properties. Bioresour. Technol. 2001, 79, 267-272.

18. Cheng, C.; Asada, Y.; Aaida, T. Production of $\gamma$-polyglutamic acid by Bacillus subtilis A35 under denitrifying conditions. Agric. Biol. Chem. 1989, 53, 2369-2375.

19. Kubota, H.; Matsunobu, T.; Uotani, K.; Takebe, H.; Satoh, A.; Tanaka, T.; Taniguchi, M. Production of poly $(\gamma$-glutamic acid) by Bacillus subtilis F-2-01. Biosci. Biotech. Biochem. 1993, 57, 1212-1213. [CrossRef]

20. Cromwick, A.M.; Birrer, G.A.; Gross, R.A. Effects of $\mathrm{pH}$ and aeration on gamma-poly(glutamic acid) formation by Bacillus licheniformis in controlled batch fermentor cultures. Biotechnol. Bioeng. 1996, 50, $222-227$. [CrossRef]

21. Zanuy, D.; Aleman, C.; MunozGuerra, S. On the helical conformation of unionized poly( $\gamma$-D-glutamic acid). Int. J. Biol. Macromol. 1998, 23, 175-184. [CrossRef]

22. Bajaj, I.B.; Singhal, R.S. Effect of Aeration and Agitation on Synthesis of Poly ( $\gamma$-glutamic acid) in Batch Cultures of Bacillus licheniformis NCIM 2324. Biotechnol. Bioproc. Eng. 2010, 15, 635-640. [CrossRef]

23. Yoon, S.H.; Do, J.H.; Lee, S.Y.; Chang, H.N. Production of poly- $\gamma$-glutamic acid by fed-batch culture of Bacillus licheniformis. Biotechnol. Lett. 2000, 22, 585-588. [CrossRef]

24. Jeong, G.T.; Kim, J.N.; Ryu, H.W.; Wee, Y.J. Improved production of poly( $\gamma$-glutamic acid) by Bacillus subtilis RKY3 and its recovery from viscous fermentation broth as a biodegradable polymer. J. Chem. Technol. Biotechnol. 2014, 89, 728-734. [CrossRef]

25. Bajaj, I.B.; Lele, S.S.; Singhal, R.S. A statistical approach to optimization of fermentative production of poly( $\gamma$-glutamic acid) from Bacillus licheniformis NCIM 2324. Bioresour. Technol. 2009, 100, 826-832. [CrossRef] 